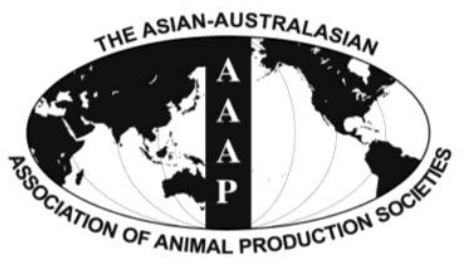

Asian Australas. J. Anim. Sci.

Vol. 26, No. 7 : 1003-1011 July 2013

http://dx.doi.org/10.5713/ajas.2012.12555

www.ajas.info

pISSN 1011-2367 elSSN 1976-5517

\title{
Effects of Dietary Lysine Levels on Apparent Nutrient Digestibility and Serum Amino Acid Absorption Mode in Growing Pigs
}

\author{
P. L. Zeng ${ }^{a}$, H. C. Yan ${ }^{\text {a }, ~ X . ~ Q . ~ W a n g *, ~ C . ~ M . ~ Z h a n g, ~ C . ~ Z h u, ~ G . ~ S h u, ~ a n d ~ Q . ~ Y . ~ J i a n g ~}$ \\ Guangdong Provincial Key Laboratory of Agro-Animal Genomics and Molecular Breeding, \\ Department of Animal Science, South China Agricultural University, Guangzhou, 510642, China
}

\begin{abstract}
Two experiments were conducted to determine the effects of different dietary lysine levels on the apparent nutrient digestibility, the serum amino acid (AA) concentration, and the biochemical parameters of the precaval and portal vein blood in growing pigs. In Experiment 1, 15 noncannulated pigs received diets with different lysine densities $(0.65 \%, 0.95 \%$, and $1.25 \%$ lysine) for 13 d. A total collection digestion test was performed, and blood samples were collected from the precaval vein at the end of the experiment. In Experiment 2, four cannulated pigs were fed the same diets of Experiment 1. The experiment used a self-control experimental design and was divided into three periods. On d 5 of each period, at $0.5 \mathrm{~h}$ before feeding and hourly up to $8 \mathrm{~h}$ after feeding, single blood samples were collected from catheters placed in the portal vein. In Experiment 1, some serum AAs (including lysine), serum urinary nitrogen (SUN), and total protein (TP) concentrations were significantly affected by the dietary lysine levels $(\mathrm{p}<0.05)$. Moreover, the $0.65 \%$ lysine treatment showed a significant lower apparent digestibility of gross energy, dry matter, crude protein, and phosphorus than the other treatments $(\mathrm{p}<0.05)$. In Experiment 2, serum lysine, histidine, phenylalanine, threonine, valine, isoleucine $(\mathrm{p}=0.0588)$, triglyceride, and SUN ( $\mathrm{p}=0.0572)$ concentrations were significantly affected by the dietary lysine levels $(\mathrm{p}<0.05)$. Additionally, almost all of the determined serum AA and total AA concentrations reached their lowest values at $0.5 \mathrm{~h}$ before feeding and their highest values at $2 \mathrm{~h}$ after feeding $(\mathrm{p}<0.05)$. These findings indicate that the greatest absorption of AA occurred at $2 \mathrm{~h}$ after feeding and that the dynamic profile of serum AA is affected by the dietary lysine levels. Moreover, when the dietary lysine content was $0.95 \%$, the growing pigs achieved a better nutrient digestibility and serum metabolites levels. (Key Words: Lysine, Nutrient Digestibility, Amino Acid, Biochemical Parameter, Pig)
\end{abstract}

\section{INTRODUCTION}

Amino acids are not only important substrates for the synthesis of proteins and other nitrogenous compounds, but also key regulators of fluxes through major metabolic pathways (Meijer, 2003; Jobgen et al., 2006). In growing pigs, lysine is the first limiting amino acid, and the dietary addition of lysine to the diet plays an important role in metabolism (Stoll et al., 1998a). Furthermore, lysine is directly absorbed by the intestine for protein synthesis and other metabolic processes, such as the regulation of NO synthesis, antiviral activity, protein methylation, acetylation, ubiquitination, and O-linked glycosylation (Wu, 2009). A deficiency or excess of lysine can reduce or increase $\mathrm{N}$ retention and whole-body protein turnover (Roy et al.,

\footnotetext{
* Corresponding Author: X. Q. Wang. Tel: +86-020-38295462, Fax: +86-020-38295462, E-mail: xqwang@scau.edu.cn

${ }^{\mathrm{a}}$ These authors contributed equally to this paper. Submitted Oct. 8, 2012; Accepted Dec. 28, 2012; Revised Mar. 26, 2013
}

2000; Ren et al., 2007). Consequently, growth performance, carcass characteristics (Loughmiller et al., 1998; Apple et al., 2004), serum parameters (Henry et al., 1992; Cameron et al., 2003), and nutrient digestibility (Cho et al., 1999; Yang et al., 2008; Kim et al., 2011) can be influenced by the dietary level of lysine.

After ingestion, the amino acids released by the gastrointestinal digestion of dietary proteins are absorbed through the apical membrane of the small intestine and then subjected to sequential anabolic sequestration into the splanchnic and peripheral protein pools. A portion of the amount of dietary amino acids is metabolized by the intestine before entering the blood vessels. Intestinal amino acid metabolism involves multiple processes including protein synthesis and degradation, the transit of amino acids, arterio-portal differences, and first pass amino acid metabolism (Baracos, 2004). The portal vein is important for securing the exogenous $\mathrm{N}$ that is utilized by parenteral tissues. Less than $100 \%$ of most of the dietary amino acids 
intake appeared as free amino acids in the portal blood, and more than $100 \%$ of the intake of some amino acids appeared in the portal blood (Stoll et al., 1998b). Observations of the dynamic profile of serum amino acids can shed light on the absorption conditions of amino acids, which is valuable information for achieving a better balance of dietary amino acids and is very important for practical production. However, information on the influence of dietary lysine on the dynamic profile of amino acids and biochemical parameters in the serum of the portal vein in growing pigs is limited. Therefore, further study of the effects of dietary lysine on the absorption mechanism of amino acids (particularly lysine) in growing pigs is important.

The objective of the present investigation was to provide further information on the absorption mode of amino acids in growing pigs by focusing on the effects of different dietary lysine levels on the serum amino acid concentrations, biochemical indices for the precaval and portal veins, and apparent nutrient digestibility in the growing pigs.

\section{MATERIALS AND METHODS}

\section{Experimental animals and diets}

In Experiment 1 (Exp. 1), 15 crossbred castrates (Large White $\times$ Landrace) with an average initial $\mathrm{BW}$ of $20 \mathrm{~kg}$ were randomly allotted to three treatments on the basis of their initial BW. The pigs were housed individually in stainlesssteel metabolic cages in a temperature-controlled room $\left(18 \pm 2^{\circ} \mathrm{C}\right)$. The pigs were fed diets containing lysine at three levels, $0.65 \%$ (low lysine, LL), $0.95 \%$ (medium lysine, ML) and $1.25 \%$ (high lysine, HL), and were trained to consume three meals (500 g each meal) daily at 08:00, 13:00, and 18:00 h. After each feeding, the feeder was cleaned, the feed refusal was recorded, and fresh water was provided in the feeder until the next feeding.

The pigs were adapted to the experimental diet for $7 \mathrm{~d}$. Fecal samples were collected from d 8 to $\mathrm{d} 13$ and stored at $-20^{\circ} \mathrm{C}$ prior to analysis. The fecal samples were pooled and dried in an air-forced drying oven at $65^{\circ} \mathrm{C}$ for $72 \mathrm{~h}$ and then ground with a 1-mm mesh Wiley mill for chemical analysis. At the end of the experiment, blood samples $(10 \mathrm{ml})$ from each pig were collected from the cranial vena cava region using syringes after a 12-h fast. After centrifugation $(2,000$ $\times \mathrm{g}$ for $20 \mathrm{~min}$ ), the serum samples were stored at $-20^{\circ} \mathrm{C}$ for subsequent analysis.

Four pigs with an average initial BW of $37.8 \mathrm{~kg}$ were used in Experiment 2 (Exp. 2), at the end of Exp. 1. After a 10-d adjustment period, feed (the basal diet) was withdrawn from the pigs for $12 \mathrm{~h}$. The pigs were surgically fitted with chronic catheters in the portal vein, as described by Stoll et al. (1998b) with some modification (Huang et al., 2003; Li et al., 2008). In brief, a 2-cm stainless-steel tube ((2.41 mm outside diameter $(\mathrm{OD}) \times 1.68 \mathrm{~mm}$ inside diameter (ID)) was constructed using a luerstus-15 g adapter (VWR International Ltd, Mississauga, ON, Canada) and inserted into the top tip of a portal-vein catheter (Micro-Renathane tubing, $2.41 \mathrm{~mm}$ OD $\times 1.68 \mathrm{~mm}$ ID; Braintree Scientific Inc., NY, USA). The portal vein was punctured with a No. 12 needle. Using an introducer, the portal-vein catheter was then inserted into the portal vein, 4 to $6 \mathrm{~cm}$ toward the liver. After surgery, the pigs were returned to their metabolic cages for recovery. Intramuscular injections of penicillin $\left(1.6 \times 10^{5} \mathrm{IU}\right)$ were given to the experimental pigs every day for the next $5 \mathrm{~d}$. All catheters were rinsed daily with $5 \mathrm{ml}$ heparin solution $(400 \mathrm{IU} / \mathrm{ml})$. To prevent blood vessel blockage, $3 \mathrm{ml}$ blood was withdrawn from the catheter every three days. Medicinal ointment was applied around the catheter exit to relieve itching and to prevent wound infection.

The day after surgery, each pig was given one-third of its pre-surgery daily feed intake and was returned to its preoperative intake at $\mathrm{d} 4$. During the recovery period, the pigs had free access to drinking water and the basal diet. After a $10-d$ period of recovery from the surgery, the pigs were assigned to dietary treatments in a self-controlled experimental design method. This phase of the study was divided into three experimental periods during which the pigs were fed one experimental diet. In the first experimental period, the animals were fed the basal diet containing $0.65 \%$ lysine (LL). The diet during the second period contained $0.95 \%$ lysine (ML), and the diet during the third period contained $1.25 \%$ lysine (HL). The diets were the same as those in Exp. 1 and were offered to the animals in two equal meals at 08:00 and 20:00 h. Water was freely available after each meal. Each of these three experimental periods consisted of an adaptation phase of $4 \mathrm{~d}$. Then, on $\mathrm{d}$ 5 , blood samples from each pig were collected simultaneously from the portal vein catheters at $0.5 \mathrm{~h}$ before feeding and at 1, 2, 3, 4, 5, 6, and $8 \mathrm{~h}$ after feeding. After centrifugation $(2,000 \times \mathrm{g}$ for $20 \mathrm{~min})$, the serum samples were stored at $-20^{\circ} \mathrm{C}$ for subsequent analysis. The protocol for the care of the experimental animals was approved by the Animal Care Committee at the South China Agricultural University.

The experimental diets were the same in both experiments. All the diets met or exceeded the nutrient requirements as suggested by NRC (1998), except for crude protein, DE, and lysine. The DE requirement was defined by NY (2004), and the main characteristics and composition of diets are shown in Table 1. Crystalline L-lysine-HCL was added in equal increments to provide $0.95 \%$ or $1.25 \%$ lysine, and the contents of other amino acids were unchanged. 
Table 1. Dietary composition and nutrient levels (air-dry basis, \%)

\begin{tabular}{|c|c|c|c|}
\hline \multirow[b]{2}{*}{ Item } & \multicolumn{3}{|c|}{ Treatment $^{1}$} \\
\hline & $\begin{array}{c}0.65 \% \\
(\mathrm{LL})\end{array}$ & $\begin{array}{c}0.95 \% \\
(\mathrm{ML})\end{array}$ & $\begin{array}{c}1.25 \% \\
\text { (HL) }\end{array}$ \\
\hline \multicolumn{4}{|l|}{ Ingredients (\%) } \\
\hline Corn & 64.00 & 64.00 & 64.00 \\
\hline Soybean meal & 13.00 & 13.00 & 13.00 \\
\hline Wheat bran & 12.00 & 11.62 & 11.24 \\
\hline Maize protein meal & 9.18 & 9.18 & 9.18 \\
\hline Flour & 1.00 & 1.00 & 1.00 \\
\hline Calcium phosphate dibasic & 0.50 & 0.50 & 0.50 \\
\hline Salt & 0.20 & 0.20 & 0.20 \\
\hline Mineral mixture $^{2}$ & 0.10 & 0.10 & 0.10 \\
\hline Vitamin mixture $^{3}$ & 0.02 & 0.02 & 0.02 \\
\hline L-lysine $\cdot \mathrm{HCl}$ & 0.00 & 0.38 & 0.76 \\
\hline \multicolumn{4}{|l|}{ Calculated composition } \\
\hline $\mathrm{DE}(\mathrm{MJ} / \mathrm{kg})$ & 13.54 & 13.51 & 13.47 \\
\hline $\mathrm{CP}(\%)$ & 17.88 & 18.12 & 18.35 \\
\hline $\mathrm{Ca}(\%)$ & 0.58 & 0.58 & 0.58 \\
\hline $\mathrm{P}(\%)$ & 0.52 & 0.51 & 0.51 \\
\hline $\operatorname{Lysine}^{4}(\%)$ & $\begin{array}{c}0.65 \\
(0.73)\end{array}$ & $\begin{array}{c}0.95 \\
(1.09)\end{array}$ & $\begin{array}{c}1.25 \\
(1.37)\end{array}$ \\
\hline Methionine (\%) & 0.35 & 0.35 & 0.35 \\
\hline
\end{tabular}

${ }^{1}$ For the levels, LL, ML and HL represent the low-lysine diet, mediumlysine diet and high-lysine diet, respectively.

${ }^{2}$ Supplied as the following per kilogram of mineral mixture: Mn, 10,000 mg; Zn, 60,000 mg; Cu, 6,000 mg; Fe, 50,000 mg; I, 150 mg; Se, 100 $\mathrm{mg}$

${ }^{3}$ Supplied as the following per kilogram of vitamin mixture: Vitamin A, 6,000,000 IU; Vitamin $D_{3}, 2,000,000$ IU; Vitamin E, 3,000 IU; Vitamin C, 2,000 mg; Vitamin $K_{3}, 1,000 \mathrm{mg}$; Vitamin $B_{1}, 3,000 \mathrm{mg}$; Vitamin $B_{2}$ $5,000 \mathrm{mg}$; Vitamin $B_{6}, 1,000 \mathrm{mg}$; Vitamin $B_{12}, 2 \mathrm{mg}$; Bioepiderm, $10 \mathrm{mg}$; Calcium pantothenate, 5,000 mg; Nicotinamide, 5,000 mg; DL-Met. 10,000 mg; L-lysine, 2,000 mg; Folacin, $100 \mathrm{mg}$; and Becholine, 30,000 mg.

${ }^{4}$ The data in parentheses indicate the analyzed composition

\section{Chemical analysis}

Proximate analyses of the experimental diets and fecal samples were performed using AOAC (2002) methods. The gross energy (GE) was measured using a bomb calorimeter (WZR-1T-B) and the crude protein (CP) with a Kjeltec Auto Sampler System Analyzer (FOSS Fecator).

The apparent nutrient digestibility (CAD) of the GE, dry matter (DM), CP, crude ash (CA), and phosphorus (P) were calculated with the following equation:

$$
\mathrm{CAD}=\left(\left((\mathrm{DM})_{\operatorname{diet}}-(\mathrm{DM})_{\text {feces }}\right) /(\mathrm{DM})_{\text {diet }}\right) \times 100 \%
$$

In this equation, $\mathrm{CAD}$ represents the apparent nutrient digestibility of DM or the others (including GE, CP, CA, and $\mathrm{P})$, and $(\mathrm{DM})_{\text {diet }}$ and $(\mathrm{DM})_{\text {feces }}$ represent the concentrations $(\mathrm{mg} / \mathrm{kg} \mathrm{DMI})$ of DM and the others in the diet and feces, respectively. The CAD values for the other experimental variables were calculated using this same equation, with the appropriate values of the variable in question substituted for DM.

The amino acid concentrations in the serum samples were analyzed after treatment with sulfosalicylic acid and centrifugation according to the procedure of Kong et al. (2009). Briefly, the clear supernatant after centrifuging was filtered through a $0.45 \mu \mathrm{m}$ filtration membrane. The filtrate was placed in a sample bottle, following the instructions of the manufacturer (Model L-8900, Hitachi Ltd. Tokyo, Japan), and the amino acid concentrations were determined using an automatic amino acid analyzer.

Serum biochemical parameters, including serum triglyceride (TG), glucose (GLU), serum urea nitrogen (SUN), and total protein (TP), were analyzed with an automated chemistry analyzer (BECKMAN SYNCHRON CX5) using commercial kits.

\section{Statistical analysis}

All the data were analyzed using the Proc GLM procedure of SAS (SAS, 2001). Each pig was considered an experimental unit. Differences among the treatments in Exp. 1 were determined by Duncan's multiple-range test, and in Exp. 2, differences among the treatments were determined by repeated measures analysis. The model included the main effects of the dietary lysine level and time point in addition to all appropriate 2-way interactions. The data were presented as the means \pm SEM. The differences between the treatments were considered statistically significant at a $\mathrm{p}<0.05$ level.

\section{RESULTS}

\section{Apparent nutrient digestibility}

In Exp. 1, increases (group HL) in the dietary lysine level reduced $(p>0.05)$ the apparent nutrient digestibility compared to group ML (Table 2). The apparent digestibilities of the nutrients detected (with the exception of CA) were higher $(p<0.05)$ in group ML than in group $L L$,

Table 2. Effects of different dietary lysine levels on the apparent nutrient digestibility in the growing pigs in Experiment 1 (DM basis, \%; mean of 5 replicates of one pig each)

\begin{tabular}{lcccl}
\hline \multirow{2}{*}{ Item $^{2}$} & \multicolumn{4}{c}{ Lysine level $^{1}$} \\
\cline { 2 - 5 } & $0.65 \%(\mathrm{LL})$ & $0.95 \%(\mathrm{ML})$ & $1.25 \%(\mathrm{HL})$ & $\mathrm{SEM}^{3}$ \\
\hline $\mathrm{GE}$ & $81.84^{\mathrm{b}}$ & $84.28^{\mathrm{a}}$ & $83.50^{\mathrm{a}}$ & 0.48 \\
$\mathrm{DM}$ & $82.40^{\mathrm{b}}$ & $84.36^{\mathrm{a}}$ & $83.46^{\mathrm{ab}}$ & 0.45 \\
$\mathrm{CP}$ & $76.73^{\mathrm{b}}$ & $81.77^{\mathrm{a}}$ & $79.23^{\mathrm{ab}}$ & 1.11 \\
$\mathrm{CA}$ & 31.55 & 35.5 & 33.25 & 2.22 \\
$\mathrm{P}$ & $81.51^{\mathrm{b}}$ & $83.78^{\mathrm{a}}$ & $82.73^{\mathrm{ab}}$ & 0.54 \\
\hline
\end{tabular}

${ }_{a, b}$ Means with different superscripts in the same row differ at the $p<0.05$ level.

${ }^{1}$ For the levels, LL, ML and HL represent the low-lysine diet, mediumlysine diet and high-lysine diet, respectively.

2 For the items, GE = Gross energy, DM $=$ Dry matter, $\mathrm{CP}=$ Crude protein, $\mathrm{CA}=$ Crude ash and $\mathrm{P}=$ Phosphorus.

${ }^{3}$ Standard error of means. 
and the digestibility of GE was lower $(\mathrm{p}<0.05)$ in group LL than in groups ML and HL.

\section{Serum amino acid concentration}

The differences in the serum concentration of amino acids in the precaval (Exp. 1) and portal veins (Exp. 2) are shown in Table 3 and 4, respectively.

In Exp. 1, the serum concentration of lysine was higher $(p<0.05)$ in the group when pigs were fed the diet containing $0.95 \%$ lysine than in group HL, meanwhile the serum glutamic acid serum concentration was higher $(p<0.05)$ in group ML than in group LL. In contrast, the serum concentration of serine was lower $(\mathrm{p}<0.05)$ for the ML diet than for the other diets, and the serum concentration of threonine was lower $(p<0.01)$ in group ML than in group LL. Group HL exhibited a lower serum concentration of tyrosine $(p<0.01)$ compared with the ML and LL groups. Most other serum amino acid concentrations were lower in group ML than in the other groups, with the exception of alanine, aspartic acid, histidine, and leucine $(\mathrm{p}>0.05)$.

In Exp. 2, the serum concentrations of lysine was increased $(\mathrm{p}<0.05)$ as the dietary lysine levels increased. In contrast, the serum concentrations of isoleucine $(p=0.0588)$, histidine, phenylalanine, threonine, and valine were decreased $(\mathrm{p}<0.05)$. The serum concentrations of the other amino acids detected did not differ among the treatments ( $p>0.05)$. The serum concentrations of almost all the amino acids examined (with the exception of glycine) and of the total amino acids were affected $(\mathrm{p}<0.05)$ by the collection time points. Moreover, the serum lysine concentrations in
Table 3. Effects of different dietary lysine levels on the serum amino acid concentrations in the growing pigs in Experiment 1 $(\mu \mathrm{mol} / \mathrm{ml}$; mean of 5 replicates of one pig each)

\begin{tabular}{|c|c|c|c|c|}
\hline \multirow[b]{2}{*}{ Amino acid } & \multicolumn{4}{|c|}{ Lysine level $^{1}$} \\
\hline & $\begin{array}{c}0.65 \% \\
(\mathrm{LL})\end{array}$ & $\begin{array}{l}0.95 \% \\
(\mathrm{ML})\end{array}$ & $\begin{array}{c}1.25 \% \\
(\mathrm{HL})\end{array}$ & SEM $^{2}$ \\
\hline Lysine (Lys) & $0.088^{\mathrm{ab}}$ & $0.108^{\mathrm{a}}$ & $0.080^{\mathrm{b}}$ & 0.007 \\
\hline Alanine (Ala) & 0.398 & 0.430 & 0.417 & 0.028 \\
\hline Arginine (Arg) & 0.168 & 0.163 & 0.187 & 0.020 \\
\hline Aspartic acid (Aps) & 0.035 & 0.043 & 0.047 & 0.007 \\
\hline Glutamic acid (Glu) & $0.230^{\mathrm{b}}$ & $0.345^{\mathrm{a}}$ & $0.290^{\mathrm{ab}}$ & 0.030 \\
\hline Glycine (Gly) & 1.135 & 1.015 & 1.030 & 0.137 \\
\hline Histidine (His) & 0.115 & 0.120 & 0.110 & 0.008 \\
\hline Isoleucine (Ile) & 0.098 & 0.080 & 0.097 & 0.009 \\
\hline Leucine (Leu) & 0.208 & 0.220 & 0.200 & 0.020 \\
\hline Phenylalanine (Phe) & 0.093 & 0.078 & 0.083 & 0.006 \\
\hline Proline (Pro) & 0.293 & 0.285 & 0.300 & 0.018 \\
\hline Serine (Ser) & $0.193^{\mathrm{a}}$ & $0.143^{\mathrm{b}}$ & $0.187^{\mathrm{a}}$ & 0.013 \\
\hline Threonine (Thr) & $0.250^{\mathrm{A}}$ & $0.143^{\mathrm{B}}$ & $0.210^{\mathrm{AB}}$ & 0.018 \\
\hline Tyrosine (Tyr) & $0.098^{\mathrm{A}}$ & $0.093^{\mathrm{A}}$ & $0.043^{\mathrm{B}}$ & 0.009 \\
\hline Valine (Val) & 0.255 & 0.210 & 0.250 & 0.016 \\
\hline Total amino acid (Total) & 3.698 & 3.503 & 3.600 & 0.181 \\
\hline \multicolumn{5}{|c|}{$\begin{array}{l}\mathrm{a}, \mathrm{b} \\
\text { Means with different superscripts in the same row differ at the } \mathrm{p}<0.05 \\
\text { level. }\end{array}$} \\
\hline
\end{tabular}

all three groups were the greatest at $1 \mathrm{~h}$ after feeding (Figure 1A). In the ML group, the serum concentrations of almost all determined amino acids reached their peak values

Table 4. Effects of different dietary lysine levels on serum concentrations of amino acids in growing pigs in Experiment 2 ( $\mu$ mol/ml; mean of 4 replicates of one pig each)

\begin{tabular}{|c|c|c|c|c|c|c|c|c|c|c|c|c|c|c|c|c|}
\hline \multirow{2}{*}{$\begin{array}{l}\text { Amino } \\
\text { acid }\end{array}$} & \multicolumn{5}{|c|}{ Level $^{1}$} & \multicolumn{10}{|c|}{ Time $^{2}$} & \multirow{2}{*}{ 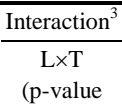 } \\
\hline & LL & ML & $\mathrm{HL}$ & $\mathrm{SEM}^{4}$ & $\mathrm{p}$-value & B $0.5 \mathrm{~h}$ & A $1 \mathrm{~h}$ & A $2 \mathrm{~h}$ & A $3 \mathrm{~h}$ & A $4 \mathrm{~h}$ & A $5 \mathrm{~h}$ & A $6 \mathrm{~h}$ & A $8 \mathrm{~h}$ & SEM & $\mathrm{p}$-value & \\
\hline Lys & 0.109 & 0.184 & 0.368 & 0.031 & $<0.0001$ & 0.101 & 0.377 & 0.372 & 0.308 & 0.226 & 0.191 & 0.148 & 0.123 & 0.036 & $<0.0001$ & $<0.0001$ \\
\hline Ala & 0.662 & 0.590 & 0.637 & 0.030 & 0.4840 & 0.488 & 0.809 & 0.823 & 0.721 & 0.634 & 0.574 & 0.513 & 0.461 & 0.030 & $<0.0001$ & 0.0530 \\
\hline Arg & 0.238 & 0.206 & 0.223 & 0.012 & 0.2683 & 0.148 & 0.257 & 0.295 & 0.275 & 0.238 & 0.209 & 0.185 & 0.162 & 0.012 & $<0.0001$ & 0.2856 \\
\hline Asp & 0.041 & 0.029 & 0.025 & 0.002 & 0.0813 & 0.033 & 0.033 & 0.035 & 0.034 & 0.033 & 0.027 & 0.026 & 0.025 & 0.003 & $<0.0001$ & 0.6359 \\
\hline Glu & 0.366 & 0.341 & 0.377 & 0.011 & 0.2338 & 0.397 & 0.377 & 0.387 & 0.378 & 0.378 & 0.328 & 0.332 & 0.311 & 0.015 & 0.0001 & 0.0932 \\
\hline Gly & 0.960 & 0.953 & 1.064 & 0.020 & 0.1103 & 0.929 & 0.993 & 1.018 & 1.000 & 1.008 & 1.007 & 0.996 & 1.017 & 0.032 & 0.1155 & 0.2120 \\
\hline His & 0.144 & 0.122 & 0.116 & 0.005 & 0.0053 & 0.096 & 0.144 & 0.152 & 0.145 & 0.129 & 0.123 & 0.112 & 0.104 & 0.005 & $<0.0001$ & 0.0047 \\
\hline Ile & 0.154 & 0.138 & 0.129 & 0.007 & 0.0588 & 0.095 & 0.171 & 0.179 & 0.170 & 0.139 & 0.131 & 0.114 & 0.113 & 0.007 & $<0.0001$ & 0.0025 \\
\hline Leu & 0.465 & 0.420 & 0.419 & 0.020 & 0.2602 & 0.273 & 0.488 & 0.531 & 0.533 & 0.466 & 0.431 & 0.380 & 0.355 & 0.021 & $<0.0001$ & 0.0172 \\
\hline Phe & 0.198 & 0.171 & 0.160 & 0.007 & 0.0008 & 0.120 & 0.190 & 0.211 & 0.211 & 0.188 & 0.172 & 0.155 & 0.150 & 0.008 & $<0.0001$ & 0.0115 \\
\hline Pro & 0.541 & 0.482 & 0.479 & 0.023 & 0.3447 & 0.316 & 0.574 & 0.628 & 0.606 & 0.525 & 0.488 & 0.441 & 0.397 & 0.022 & $<0.0001$ & 0.0473 \\
\hline Ser & 0.276 & 0.264 & 0.277 & 0.012 & 0.7234 & 0.185 & 0.315 & 0.337 & 0.320 & 0.278 & 0.270 & 0.244 & 0.232 & 0.012 & $<0.0001$ & 0.0005 \\
\hline Thr & 0.750 & 0.426 & 0.388 & 0.037 & 0.0002 & 0.370 & 0.554 & 0.616 & 0.580 & 0.513 & 0.479 & 0.441 & 0.452 & 0.056 & $<0.0001$ & 0.0101 \\
\hline Tyr & 0.236 & 0.228 & 0.241 & 0.007 & 0.7723 & 0.187 & 0.251 & 0.269 & 0.263 & 0.244 & 0.232 & 0.219 & 0.217 & 0.008 & $<0.0001$ & 0.0019 \\
\hline Val & 0.335 & 0.267 & 0.233 & 0.012 & 0.0004 & 0.211 & 0.311 & 0.335 & 0.319 & 0.281 & 0.261 & 0.237 & 0.230 & 0.016 & $<0.0001$ & 0.0052 \\
\hline Total & 5.606 & 4.945 & 5.217 & 0.184 & 0.1432 & 4.018 & 5.977 & 6.332 & 5.937 & 5.375 & 5.052 & 4.660 & 4.441 & 0.191 & $<0.0001$ & 0.0128 \\
\hline
\end{tabular}

${ }^{1}$ For the levels, LL, ML and HL represent the low-lysine diet, medium-lysine diet and high-lysine diet, respectively.

${ }^{2}$ For the time, B $0.5 \mathrm{~h}$ indicates $0.5 \mathrm{~h}$ before feeding; and A $1 \mathrm{~h}$ indicates $1 \mathrm{~h}$ after feeding, with A $2 \mathrm{~h}, \mathrm{~A} 3 \mathrm{~h}, \mathrm{~A} 4 \mathrm{~h}, \mathrm{~A} 5 \mathrm{~h}$, A $6 \mathrm{~h}$, and A $8 \mathrm{~h}$ indicating the respective time point after feeding.

${ }^{3}$ For the interactions, $\mathrm{L}$ and $\mathrm{T}$ represent the main effects of level and time, respectively.

${ }^{4}$ Standard error of means. 

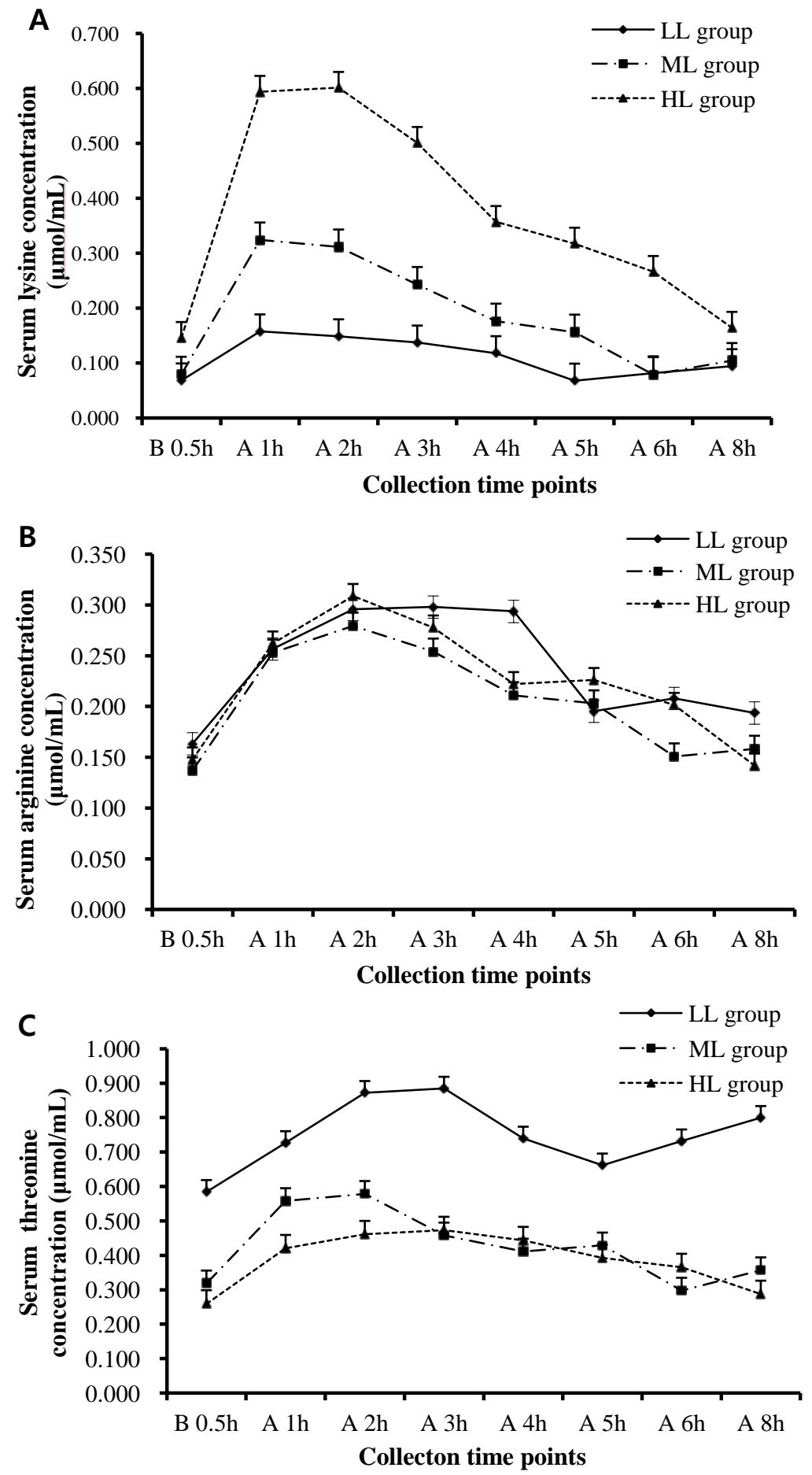

Figure 1. The changes in the concentrations of serum lysine, arginine, and threonine in the portal vein in the LL, ML, and HL groups at the collection times. B $0.5 \mathrm{~h}$ indicates $0.5 \mathrm{~h}$ before feeding and A $1 \mathrm{~h}$ indicates $1 \mathrm{~h}$ after feeding, with A $2 \mathrm{~h}, \mathrm{~A} 3 \mathrm{~h}, \mathrm{~A} 4 \mathrm{~h}, \mathrm{~A} 5 \mathrm{~h}, \mathrm{~A} 6 \mathrm{~h}$, and A $8 \mathrm{~h}$ indicating the respective time point after feeding.

at $2 \mathrm{~h}$ after feeding, whereas the serum concentrations of arginine (Figure 1B), glycine, isoleucine, leucine, phenylalanine, serine, threonine (Figure 1C), and tyrosine and the total amino acids in the LL group reached their peak values at a later time point, $3 \mathrm{~h}$ after feeding (the data above were not shown here). In summary, the serum concentrations of almost all of the amino acids examined and of the total amino acids were the lowest at $0.5 \mathrm{~h}$ before feeding and the highest at $2 \mathrm{~h}$ after feeding (Table 4). Level $\times$ time interactions were found for lysine, histidine, isoleucine, leucine, phenylalanine, proline, serine, threonine, tyrosine, valine, and total amino acid $(\mathrm{p}<0.05)$; there were 
Table 5. Effects of different dietary lysine levels on the serum biochemical parameters in the growing pigs in Experiment 1 (mean of 5 replicates of one pig each)

\begin{tabular}{lcccc}
\hline \multirow{2}{*}{ Item $^{2}$} & \multicolumn{4}{c}{ Lysine level $^{1}$} \\
\cline { 2 - 5 } & $\begin{array}{c}0.65 \% \\
(\mathrm{LL})\end{array}$ & $\begin{array}{c}0.95 \% \\
(\mathrm{ML})\end{array}$ & $\begin{array}{c}1.25 \% \\
(\mathrm{HL})\end{array}$ & $\mathrm{SEM}^{3}$ \\
\hline $\mathrm{TP}(\mathrm{mg} / \mathrm{ml})$ & $53.60^{\mathrm{b}}$ & $58.10^{\mathrm{a}}$ & $59.00^{\mathrm{a}}$ & 0.95 \\
$\mathrm{TG}(\mathrm{mol} / \mathrm{ml})$ & 0.39 & 0.36 & 0.37 & 0.02 \\
$\mathrm{GLU}(\mathrm{mol} / \mathrm{ml})$ & 6.73 & 6.62 & 6.57 & 0.18 \\
SUN $(\mathrm{mol} / \mathrm{ml})$ & $5.76^{\mathrm{a}}$ & $4.50^{\mathrm{b}}$ & $3.91^{\mathrm{b}}$ & 0.26 \\
\hline
\end{tabular}

${ }_{\mathrm{a}, \mathrm{b}}$ Means with different superscripts in the same row differ at the $\mathrm{p}<0.05$ level.

${ }^{1}$ For the levels, LL, ML and HL represent the low-lysine diet, mediumlysine diet and high-lysine diet, respectively.

${ }^{2}$ For the items, $\mathrm{TP}=$ Total protein, $\mathrm{TG}=$ Triglyceride, $\mathrm{GLU}=$ Glucose, SUN = Serum urea nitrogen.

${ }^{3}$ Standard error of means.

no interactions among the other amino acids.

\section{Serum biochemical parameters}

The results of the analyses of serum biochemical parameters in Exp. 1 and Exp. 2 are presented in Table 5 and 6 , respectively.

The content of SUN was decreased $(\mathrm{p}<0.05)$ in Exp. 1, whereas the TP was increased $(\mathrm{p}<0.05)$ with increasing dietary lysine levels. Neither SUN nor TP differed between the ML and HL groups. The different dietary lysine levels did not affect the concentrations of GLU and TG.

In Exp. 2, the serum contents of TG $(\mathrm{p}<0.05)$ and SUN $(\mathrm{p}=0.0572)$ were influenced by the different dietary lysine levels, whereas the TP and GLU content was not influenced. Moreover, the serum content of TG was increased $(p<0.05)$, whereas the serum SUN content was decreased $(p<0.05)$ with increasing dietary lysine levels. Except for SUN, the serum content of TP, TG, and GLU was influenced $(p<0.05)$ by the collection time points. The serum GLU content was the highest at $1 \mathrm{~h}$ after feeding and the lowest at $0.5 \mathrm{~h}$ before feeding. A level $\times$ time interaction $(\mathrm{p}<0.05)$ was found for the TG content.

\section{DISCUSSION}

\section{Apparent nutrient digestibility}

In animals, lysine participates in many physiological processes and plays an important role in growth. A reasonable lysine level facilitates the digestion and utilization of feed nutrients by animals, which can, thus, reduce the impact of animal production on the environment. The results of Exp. 1 showed that the apparent digestibilities of the nutrients studied (with the exception of CA) were generally higher than those found in the other treatments when the dietary lysine content was $0.95 \%$, though there was no difference between the groups ML and
Table 6. Effects of different dietary lysine levels on the serum biochemical parameters in the growing pigs in Experiment 2 (mean of 4 replicates of one pig each)

\begin{tabular}{cclll}
\hline Item $^{1}$ & $\begin{array}{c}\text { TP } \\
(\mathrm{mg} / \mathrm{ml})\end{array}$ & $\begin{array}{c}\text { TG } \\
(\mathrm{mol} / \mathrm{ml})\end{array}$ & $\begin{array}{c}\text { GLU } \\
(\mathrm{mol} / \mathrm{ml})\end{array}$ & $\begin{array}{c}\text { SUN } \\
(\mathrm{mol} / \mathrm{ml})\end{array}$ \\
\hline Level $^{2}$ & & & & \\
LL & 65.26 & 0.14 & 5.88 & 5.74 \\
ML & 66.38 & 0.17 & 5.74 & 4.65 \\
HL & 64.55 & 0.19 & 5.73 & 4.04 \\
SEM & 0.51 & 0.01 & 0.22 & 0.20 \\
p-value & 0.3259 & 0.0342 & 0.9369 & 0.0572 \\
Time $^{4}$ & & & & \\
B 0.5 h & 67.75 & 0.14 & 3.92 & 4.75 \\
A 1 h & 65.83 & 0.16 & 6.81 & 4.96 \\
A 2 h & 65.28 & 0.18 & 6.28 & 4.64 \\
A 3 h & 64.77 & 0.17 & 6.28 & 4.76 \\
A 4 h & 63.69 & 0.16 & 5.22 & 4.89 \\
A 5 h & 64.25 & 0.19 & 5.88 & 4.69 \\
A 6 h & 65.27 & 0.18 & 5.91 & 4.63 \\
A 8 h & 66.41 & 0.19 & 5.90 & 4.45 \\
SEM & 0.78 & 0.01 & 0.25 & 0.33 \\
p-value & 0.0016 & 0.0164 & $<0.0001$ & 0.4923 \\
Interaction & & & & \\
L×T & 0.3117 & 0.0005 & 0.964 & 0.6034 \\
\hline
\end{tabular}

${ }^{1}$ For the items, TP = Total protein, $\mathrm{TG}=$ Triglyceride, GLU = Glucose, $\mathrm{SUN}=$ Serum urea nitrogen.

${ }^{2}$ For the levels, LL, ML and HL represent the low-lysine diet, mediumlysine diet and high-lysine diet, respectively.

${ }^{3}$ Standard error of means.

${ }^{4}$ For the time, $\mathrm{B} 0.5 \mathrm{~h}$ indicates $0.5 \mathrm{~h}$ before feeding; and $\mathrm{A} 1 \mathrm{~h}$ indicates 1 h after feeding, with A 2 h, A 3 h, A 4 h, A 5 h, A 6 h, and A 8 h indicating the respective time point after feeding.

${ }^{5}$ For the interactions, $\mathrm{L}$ and $\mathrm{T}$ represent the main effects of level and time, respectively.

HL. Excess lysine levels was previously reported to not affect the growth performance of pigs (Yen et al., 2005), which was consistent with the results of the present study. Comparable differences have also been found by Yang et al. (2008) in pigs fed lysine-restricted grower diets. Additionally, Jin et al. (2010) reported that the CP digestibility was decreased as dietary lysine was restricted. These results suggested that the dietary lysine levels could influence the apparent nutrient digestibility in pigs. We also found that different dietary lysine levels can affect the apparent nutrient digestibility in a previous study with finishing pigs (Wang et al., 2012). According to the report by $\mathrm{Wu}$ (2010), functional amino acids (e.g. arginine, glutamine, leucine) serve important regulatory functions in nutrient metabolism, protein turnover, and immune function and therefore enhance the efficiency of feed utilization by pigs. Although lysine is not considered a functional amino acid, it may influence the metabolism of nutrients by regulating the absorption of some functional amino acids or 
by regulating endocrine hormone release (Takenaka et al., 2000; Katsumata et al., 2002). The findings discussed above suggest that the diet with $0.95 \%$ lysine may increase the digestibility of nutrients, which was consistent with the NRC (1998) recommendations for 20 to $50 \mathrm{~kg}$ pigs. Moreover, the results of serum metabolites and nutrient digestibility during the treatments were relatively consistent in this study.

\section{Serum amino acid concentration}

In animals that are fed higher levels of an amino acid, the concentration of the amino acid in plasma increases rapidly and approximately linearly. However, in some cases, a high level of one amino acid is associated with a decline in other amino acids (Goodband et al., 1990; Henry et al., 1992; Roy et al., 2000; Barea et al., 2009). Roy et al. (2000) have reported that, with increasing dietary lysine levels, the plasma concentration of free lysine increased, whereas the concentrations of isoleucine, threonine, and valine decreased. Increasing levels of dietary lysine also caused an increase in the serum content of lysine, but these increasing lysine levels caused a decrease in the concentrations of other amino acids in pST-treated pigs (Goodband et al., 1990). Dietary lysine supplementation resulted in an increase in the plasma concentrations of free lysine, and a decrease in the concentrations of threonine, tyrosine, and some nonessential amino acids (Henry et al., 1992). These findings resemble the results of Exp. 2 in the present study in which the concentrations of lysine in the portal vein serum were increased with increasing dietary lysine levels. However, the converse result was obtained for many other amino acids. Increased lysine concentrations were expected for the lysine-supplemented diets (ML and HL) relative to the lysine-deficient diet (LL) because lysine will be retained intracellularly at low dietary lysine concentrations for preferential channeling into protein synthesis rather than for oxidation or release into the blood circulation. At low values of amino acid intake, aminoacyl tRNA synthetases have a higher affinity for their respective amino acid than the enzyme catabolizing that amino acid (Harper, 1986). Wang et al. (2012) have also found that the mRNA abundances of cationic amino acid transporters in the small intestine of finishing pigs were affected by the dietary lysine levels.

In Exp. 1, the serum concentration of lysine in the precaval vein was not increased with increasing dietary lysine levels and was higher in ML than in the other treatments. The concentrations of other amino acids (glutamic acid, serine, and threonine) in ML were either higher or lower than those found in the other treatments. The reasons for these findings may be that lysine deficiency results in an imbalanced pattern of amino acids in the liver.
In the liver, where the removal of excess amino acids can occur through increases in oxidation, in protein synthesis, or even in the size of the organ's free amino acid pool (Roy et al., 2000). Moreover, excess amino acids resulting from an overall amino acid imbalance or antagonism (the mutually adverse and opposing actions of different amino acids) can produce severe adverse effects, including reduced food intake, abnormal behavior, and more (Wu, 2009). Different experimental designs and developmental stages may also have accounted for the differences in the results of the two experiments. The blood delivers amino acids to all other tissues where they serve as building blocks for protein synthesis, precursors for a wide variety of bioactive molecules, and energy metabolites (Bröer, 2008). Venous blood from parenteral tissues converges at the precaval vein, whereas blood from the gastrointestinal tissues converges at the portal vein. One effect of metabolism by parenteral tissues is that the concentrations of amino acids in the precaval vein will differ from those in the portal vein. However, the results obtained for the serum concentration of lysine and for nutrient digestibility during the treatments were relatively consistent. These variables showed higher values in the pigs fed a diet containing $0.95 \%$ lysine.

Interestingly, the concentrations of total amino acids were numerically lower in the ML group than in the other two groups in both experiments, which may suggest that balanced amounts of dietary amino acids resulted in more effective utilization by the organism. This needs to be further studied. Furthermore, the serum concentrations in the ML group of almost all of the amino acids studied were the highest at $2 \mathrm{~h}$ after feeding in Exp. 2, whereas these concentrations took longer to reach their peak values in the LL group. This finding may indicate that dietary lysine deficiency can decrease the efficiency of amino acid utilization. The results of Exp. 2 showed that for the amino acids detected, almost all of the concentrations in the serum of the portal vein attained their highest values at $2 \mathrm{~h}$ after feeding and their lowest values at $0.5 \mathrm{~h}$ before feeding. Zhang et al. (2006) have reported that the lysine concentration in the serum of the precaval vein attained a maximum value at $1.5 \mathrm{~h}$ after feeding. These results indicate that the highest absorption of amino acids occurs from 1.5 to $2 \mathrm{~h}$ after feeding. This finding could reflect the fact that the peristalsis of the gastrointestinal tract is strongest at this time.

\section{Serum biochemical indices}

The serum metabolite profile may reflect changes in metabolic and physiological activities in response to dietary manipulations, which are likely to affect the metabolite profile, possibly through the modulation of enzymes 
associated with $\mathrm{N}$ and lipid metabolism (Clarke and Abraham, 1992; McNeel and Mersmann, 2000). Serum total protein (TP) is an indicator of protein metabolism in animals, and high concentrations of TP show that the deposition of body protein is at a high level. Decreasing dietary lysine levels caused a decrease in the concentration of TP in Exp. 1, whereas the lysine level did not cause a decrease in Exp 2. However, the TP concentration in ML was numerically higher in both experiments. These findings were agreed with the reports of Yang et al. (2008) and Kamalakar et al. (2009) that lysine deficiency decreased the concentration of TP. In contrast, SUN has been used as a predictor of dietary amino acid requirements (Cameron et al., 2003; Barea et al., 2009), whereby a low SUN concentration shows that the body protein deposition is at a high level. In the present study, the SUN concentrations decreased with increasing levels of dietary lysine in both experiments, which were consistent with the results of the studies by Goodband et al. (1990), Fernandez-Figares et al. (2007) and Jin et al. (2010).

In Exp. 1, the concentrations of TG and GLU were unaffected by the different dietary lysine levels. Although the TG concentrations were increased with increases in the dietary lysine levels in Exp. 2, the TG concentrations between groups ML and HL were not different. This finding was consistent with the report of Kamalakar et al. (2009) that lysine deficiency did not affect the concentrations of TG and GLU during the grower phase. Moreover, other studies (Yen et al., 2005; Ren et al., 2007) have also found that the plasma glucose concentration did not differ significantly among different dietary lysine treatments. The reason for this result might be that the same amount of digestible energy was provided in all of the treatments, thus the energy requirements of the growing pigs were met.

In conclusion, the highest amino acid absorption occurred at $2 \mathrm{~h}$ after feeding. Our data indicate that the dynamic profile of serum amino acids is affected by different dietary lysine levels. Moreover, the diet containing $0.95 \%$ lysine provide optimal nutrient digestibility and serum metabolites and are suitable for the growing pigs in this study.

\section{ACKNOWLEDGEMENTS}

The work was supported by National Basic Research Program of China (2013CB127302), The National 948 Project of China (2011-G35), Special Fund for Agroscientific Research in the Public Interest (201003011), Educational Commission of Guangdong Province, China (2012CXZD0015), and Science and Technology Planning Project of Guangdong Province, China (2012B020305006, 2011B090400190).

\section{REFERENCES}

AOAC. 2002. Official methods of analysis. 17th edn. Association of Official Analytical Chemists, Arlington, Virginia.

Apple, J. K., C. V. Maxwell, D. C. Brown, K. G. Friesen, R. E. Musser, Z. B. Johnson, and T. A. Armstrong. 2004. Effects of dietary lysine and energy density on performance and carcass characteristics of finishing pigs fed ractopamine. J. Anim. Sci. 82:3277-3287.

Baracos, V. 2004. Animal models of amino acid metabolism: a focus on the intestine. J. Nutr. 134:1656S-1659S.

Barea, R., L. Brossard, N. Le Floc'h, Y. Primot, and J. van Milgen. 2009. The standardized ileal digestible isoleucine-to-lysine requirement ratio may be less than fifty percent in eleven-to twenty-three-kilogram piglets1. J. Anim. Sci. 87:4022-4031.

Bröer, S. 2008. Amino acid transport across mammalian intestinal and renal epithelia. Physiol. Rev. 88:249-286.

Cameron, N. D., E. McCullough, K. Troup, and J. C. Penman. 2003. Serum urea concentration as a predictor of dietary lysine requirement in selected lines of pigs. J. Anim. Sci. 81:91-100.

Cho, W. T., J. H. Kim, I. K. Han, Y. K. Han, K. N. Heo, and J. Odle. 1999. Effects of L-carnitine with different lysine levels on growth and nutrient digestibility in pigs weaned at 21 days of age. Asian-Aus. J. Anim. Sci. 12:799-805.

Clarke, S., and S. Abraham. 1992. Gene expression: nutrient control of pre-and posttranscriptional events. FASEB J. 6: 3146-3152.

Fernández-Fígares, I., M. Lachica, R. Nieto, M.G. Rivera-Ferre, and J. F. Aguilera. 2007. Serum profile of metabolites and hormones in obese (Iberian) and lean (Landrace) growing gilts fed balanced or lysine deficient diets. Livest. Sci. 110:73-81.

Goodband, R. D., J. L. Nelssen, R. H. Hines, D. H. Kropf, R. C. Thaler, B. R. Schricker, G. E. Fitzner, and A. J. Lewis. 1990. The effects of porcine somatotropin and dietary lysine on growth performance and carcass characteristics of finishing swine. J. Anim. Sci. 68:3261-3276.

Harper, A. E. 1986. Enzymatic basis for adaptive changes in amino acid metabolism. In: Proceedings of the XIII International Congress of Nutrition, London, U.K. pp. 409-414.

Henry, Y., Y. Colleaux, and B. Seve. 1992. Effects of dietary level of lysine and of level and source of protein on feed intake, growth performance, and plasma amino acid pattern in the finishing pig. J. Anim. Sci. 70:188-195.

Huang, R. L., Y. L. Yin, T. J. Li, J. P. Gao, and L. H. Tao. 2003. Techniques for implanting a chronic hepatic portal vein transonic flow meter and catheters in the hepatic portal vein, ileal mesenteric vein and carotid artery in swine. Acta Zoonutrimenta Sinica. 15 (Suppl. 1):10-20.

Jin, Y. H., H. K. Oh, L. G. Piao, S. K. Jang, Y. H. Choi, P. S. Heo, Y. D. Jang, and Y. Y. Kim. 2010. Effect of dietary lysine restriction and energy density on performance, nutrient digestibility and meat quality in finishing pigs. Asian-Aust. J. Anim. Sci. 23:1213-1220.

Jobgen, W., S. Fried, W. Fu, C. Meininger, and G. Wu. 2006. Regulatory role for the arginine-nitric oxide pathway in metabolism of energy substrates. J. Nutr. Biochem. 17:571-588.

Kamalakar, R. B., L. I. Chiba, K. C. Divakala, S. P. Rodning, E. G. Welles, W. G. Bergen, C. R. Kerth, D. L. Kuhlers, and N. K. Nadarajah. 2009. Effect of the degree and duration of early 
dietary amino acid restrictions on subsequent and overall pig performance and physical and sensory characteristics of pork. J. Anim. Sci. 87:3596-3606.

Katsumata, M., S. Kawakami, Y. Kaji, R. Takada, and M. J. Dauncey. 2002. Differential regulation of porcine hepatic IGFI mRNA expression and plasma IGF-I concentration by a low lysine diet. J. Nutr. 132:688-692.

Kim, Y. W., S. L. Ingale, J. S. Kim, K. H. Kim, and B. J. Chae. 2011. Effects of dietary lysine and energy levels on growth performance and apparent total tract digestibility of nutrients in weanling pigs. Asian-Aust. J. Anim. Sci. 24:1256-1267.

Kong, X. F., Y. L. Yin, Q. H. He, F. G. Yin, H. J. Liu, T. J. Li, R. L. Huang, M. M. Geng, Z. Ruan, Z. Y. Deng, M. Y. Xie, and G. Y. Wu. 2009. Dietary supplementation with Chinese herbal powder enhances ileal digestibilities and serum concentrations of amino acids in young pigs. Amino Acids 37:573-582.

Li, T. J., Q. Z. Dai, Y. L Yin, J. Zhang, R. L. Huang, Z. Ruan, Z. Deng, and M. Xie. 2008. Dietary starch sources affect net portal appearance of amino acids and glucose in growing pigs. Animal 2:723-729.

Loughmiller, J. A., J. L. Nelssen, R. D. Goodband, M. D. Tokach, E. C. Titgemeyer, and I. H. Kim. 1998. Influence of dietary lysine on growth performance and carcass characteristics of late-finishing gilts. J. Anim. Sci. 76:1075-1080.

McNeel, R., and H. Mersmann. 2000. Nutritional deprivation reduces the transcripts for transcription factors and adipocytecharacteristic proteins in porcine adipocytes1. J. Nutr Biochem. 11:139-146.

Meijer, A. 2003. Amino acids as regulators and components of nonproteinogenic pathways. J. Nutr. 133:2057S-2062S.

NRC. 1998. Nutrient requirements of swine. (10th Ed.). National Academy Press, Washington, DC.

NY. 2004. Feeding standard of swine. Ministry of Agriculture Press, China.

Ren, J. B., G. Y. Zhao, Y. X. Li, and Q. X. Meng. 2007. Influence of dietary lysine level on whole-body protein turnover, plasma IGF-I, GH and insulin concentration in growing pigs. Livest. Sci. 110:126-132.
Roy, N., H. Lapierre, and J. Bernier. 2000. Whole-body protein metabolism and plasma profiles of amino acids and hormones in growing barrows fed diets adequate or deficient in lysine. Can. J. Anim. Sci. 80:585-595.

SAS Institute Inc. 2001. SAS User's Guide: Statistics, Version 8.2. SAS Institute Inc., Cary, North Carolina.

Stoll, B., D. Burrin, J. Henry, H. Yu, F. Jahoor, and P. Reeds. 1998a. Dietary amino acids are the preferential source of hepatic protein synthesis in piglets. J. Nutr. 128:1517-1524.

Stoll, B., J. Henry, P. Reeds, H. Yu, F. Jahoor, and D. Burrin. 1998b. Catabolism dominates the first-pass intestinal metabolism of dietary essential amino acids in milk protein-fed piglets. J. Nutr. 128:606-614.

Takenaka, A., N. Oki, S.-I. Takahashi, and T. Noguchi. 2000. Dietary restriction of single essential amino acids reduces plasma insulin-like growth factor-I (IGF-I) but does not affect plasma IGF-binding protein-1 in rats. J. Nutr. 130:2910-2914.

Wang, X. Q., P. L. Zeng, Y. Feng, C. M. Zhang, J. P. Yang, G. Shu, and Q. Y. Jiang. 2012. Effects of dietary lysine levels on apparent nutrient digestibility and cationic amino acid transporter mRNA abundance in the small intestine of finishing pigs, Sus scrofa. Anim. Sci. J. 83:148-155.

Wu, G. Y. 2009. Amino acids: metabolism, functions, and nutrition. Amino Acids 37:1-17.

Wu, G. Y. 2010. Recent advances in swine amino acid nutrition. J. Anim. Sci. Biotech. 1:118-130.

Yang, Y., Z. Jin, S. Yoon, J. Choi, P. Shinde, and X. Piao. 2008. Lysine restriction during grower phase on growth performance, blood metabolites, carcass traits and pork quality in grower finisher pigs. Acta Agric Scand. A-Anim. Sci. 58:14-22.

Yen, J. T., J. Klindt, B. J. Kerr, and F. C. Buonomo. 2005. Lysine requirement of finishing pigs administered porcine somatotropin by sustained-release implant. J. Anim. Sci. 83: 2789-2797.

Zhang, H., D. Li, S. Qiao, F. Wang, X. Chen, and P. Thacker. 2006. The effect of dietary homoarginine derived from guanidination of synthetic lysine on endogenous amino acid loss and apparent and true ileal amino acid digestibility in the pig. Anim. Sci. 82:23-30. 